\title{
Perempuan dan Komunikasi Politik pada Pemilihan Umum Daerah Istimewa Yogyakarta
}

\author{
Erfina Nurussa'adah \\ Program Studi Ilmu Komunikasi, Fakultas Ekonomi dan Sosial, Universitas AMIKOM Yogyakarta \\ Jl. Ring Road Utara, Ngringin, Condongcatur, Kec. Depok, Kabupaten Sleman, Daerah Istimewa Yogyakarta 55281 \\ Corresponding author: erfina@amikom.ac.id
}

\begin{abstract}
Women are often seen as having an image that is seen as weak and inappropriate for entering politics. This study aims to analyze the role of women in political communication in general elections in the Special Region of Yogyakarta. This research uses a single case study and a phenomenological approach. The theory used in this research is the standpoint Theory by Sandra Harding and Julian T. Wood which explains that men and women have separate perspectives, and are not seen as something equal. The results showed that: 1) the existence of women's political participation in political communication in DIY (affirmative action participation), namely being a vote-getter, being an equal partner for men in gender-responsive policy-making, upholding women's human rights in the regional political stage; 2) women as political communicators in the DIY general election, namely to become a medium to connect to society and also to bridge the interests of women in particular and society in general; 3) factors that influence the role of women in the DIY general election, namely internal and external factors (Empowering Role): education level, economic independence, cultural values, and the political system. This research contributes in the form of recommendations to the government and society to increase women's empowerment in the regional political stage.
\end{abstract}

Keywords: Gender; Political Communication; The Role Of Women; Vote Getter

\begin{abstract}
Abstrak
Perempuan sering dianggap memiliki citra yang dipandang lemah dan tidak pantas untuk terjun ke dunia politik. Penelitian ini bertujuan untuk menganalisis peran perempuan dalam komunikasi politik pada pemilihan umum di Daerah Istimewa Yogyakarta. Penelitian ini menggunakan studi kasus tunggal dan pendekatan fenomenologis. Teori yang digunakan dalam penelitian ini adalah standpoint theory milik Sandra Harding dan Julian T. Wood yang memaparkan bahwa laki-laki dan perempuan mempunyai perspektif yang terpisah, dan tidak dipandang sebagai sesuatu yang setara. Hasil penelitian diperoleh bahwa: 1) adanya partisipasi politik perempuan dalam komunikasi politik di DIY (partisipasi affirmative action) yaitu menjadi vote getter, menjadi mitra setara bagi laki-laki dalam pengambilan kebijakan yang responsif gender, tegaknya hak asasi perempuan dalam panggung politik daerah; 2) perempuan sebagai komunikator politik dalam pemilihan umum DIY yaitu menjadi media penghubung ke masyarakat dan juga menjembatani kepentingan perempuan secara khusus, dan masyarakat secara umum; 3) faktor yang memengaruhi peran perempuan dalam pemilihan umum DIY yaitu faktor Internal dan eksternal (Empowering Role): tingkat pendidikan, kemandirian ekonomi, nilai budaya dan sistem politik. Penelitian ini memberikan kontribusi berupa rekomendasi kepada pemerintah dan masyarakat untuk peningkatan pemberdayaan perempuan dalam panggung politik daerah.
\end{abstract}

Kata kunci: Gender; Komunikasi politik; Peran perempuan; Vote Getter

\section{Pendahuluan}

Perempuan masuk dalam elemen pembangunan, namunbukanobjekpembangunan. Hal ini menempatkan perempuan pada subordinat dan selalu dipersepsikan kedua dibawah laki-laki. Teori feminis menyatakan bahwa ketimpangan hubungan diantara perempuan dan laki-laki "menyuburkan" bahwa perempuan itu terbelakang. Istilah pemberdayaan perempuan memiliki makna ketidakberdayaan perempuan, diskriminasi, dan ketidakadilan. Perempuan masih dianggap lemah meskipun telah menjadi wanita karir, memiliki pengahasilan sendiri dan memiliki beban yang sama dengan laki-laki di tataran domestik, namun justru menjadi bahan eksploitasi. Perempuan dianggap memiliki citra yang berbeda dengan kaum laki-laki di dunia politik. Perempuan cenderung dipandang lemah sehingga tidak cocok masuk dalam dunia politik yang dianggap kotor, dan banyak intrik. 
Di era saat ini, perempuan mulai dijunjung harkat dan martabatnya dan masuk dalam kesetaraan gender, perempuan tidak hanya berperan sebagai ibu rumah tangga yang menjalankan fungsi reproduksi, mengurus keluarga dan pekerjaan domestik yang lain. Perempuan mulai masuk dalam panggung politik dan ikut aktif dalam kegiatan sosial, ekonomi pemerintahan, meskipun keterwakilannya belum menunjukkan peningkatan yang signifikan. Fenomena bahwa 57\% perolehan suara ditentukan oleh suara perempuan, karena setengah total jumlah penduduk di Indonesia adalah perempuan, sehingga mengabaikan perempuan dalam pembuatan keputusan politik artinya meminggirkan mayoritas penduduk Indonesia dalam proses politik (Zamroni, 2016). Yuniati dan Fardiah (2017) menyatakan bahwa citra perempuan yang berani mencalonkan diri di media online kebanyakan terdiri dari orang-orang popular apakah karena faktor keartisannya atau posisinya sebagai incumbent maupun kedekatannya dengan pejabat penting.

Proses politik yang terjadi tidak terlepas dari komunikasi politik. Susanto (2013) berpendapat bahwa komunikasi politik adalah proses penyampaian pendapat, sikap, dan tingkah laku orang-orang, lembaga-lembaga atau kekuatankekuatan politik dalam rangka mempengaruhi pengambila keputusan politik, sedangkan yang dimaksud dengan politik tidak lain adalah kehidupan bernegara. Komunikasi politik menurut Rush dan Althoff yaitu memainkan peran penting dalam sebuah sistem politik. Peran dinamis menjadi bagian penentu dari proses sosialisasi politik, partisipasi politik dan rekrutmen politik. Komunikasi politik secara terbuka dapat mempengaruhi orang untuk terlibat aktif dan juga mampu menekan partisipasi politik (Nimmo, 2011). Komunikasi politik mempunyai kepentingan dalam upaya pembentukan citra politik serta menciptakan stabilitas sosial dengan memenuhi tuntutan rakyat (Muchtar, 2016).
Komunikasi politik dalam hal ini bertujuan untuk mendorong peran serta partisipasi perempuan salah satunya dalam membuat keputusan dengan menempatkan perempuan dalam panggung politik pemerintah dan masuk dalam ranah politik, sehingga keterwakilan perempuan tidak hanya untuk memenuhi kuota, namun menjadi bagian dalam memperjuangkan hak dan aspirasi perempuan serta fungsi peran perempuan benarbenar berjalan. Hal ini juga disampaikan dalam penelitian Ratnawati (2004), bahwa faktor yang cukup signifikan untuk menentukan keterwakilan perempuan yaitu melalui sistem pemilu, peran organisasi partai politik, penerimaan secara kultural dan dukungan melalui Affirmative Action yang bersifat sukarela. Penelitian Priandi dan Roisah (2019) berbeda dengan penelitian Ratnawati, yaitu menunjukkan naik turunnya keterwakilan perempuan didalam parlemen dapat dipicu karena kebijakan yang sama, karena pada dasarnya gairah kaum perempuan dalam dunia politik jika tidak ditompang dengan upaya-upaya serta kebijakan yang lebih memacu jumlah keterwakilan berakibat menurun. Hal ini dapat dilihat dari penggunakan kebijakan yang sama dari pemilu 2009 dan 2014. Kekuatiran keterwakilan perempuan menurun itu bukan berarti hilang pada 2019 meski 40 Persen perempuan masuk kedalam daftar pencalonan legislatif dipemilihan umum 2019.

Masalah strategis yang diteliti lebih jauh dalam penelitian ini, yaitu mengenai peran perempuan dalam komunikasi politik beserta segala kendala dan faktor pendukung keterlibatan. Hal ini sangat penting diteliti karena dalam perspektif politik modern, logikanya, agenda yang kongkrit untuk memajukan peran dan harkat perempuan Indonesia sudah selayaknya dijadikan salah satu tawaran utama oleh partai politik yang ingin melapangkan jalannya. Hal ini didasari oleh fenomena bahwa Daerah Istimewa Yogyakarta menjadi wilayah yang keterlibatan perempuan terus naik dari 2004 sejumlah 5\% naik menjadi 9\% di Pemilu 2009 (Data KPU, 2014). 
Terjadi peningkatan meskipun kuota minimal $30 \%$ belum terpenuhi, begitu pula pada Pemilu 2014 dan 2019. Alasan lain yang tidak kalah pentingnya tentang peran perempuan ke sektor politik adalah untuk mengetahui lebihjauh apakah terjadi perluasan scope politik ke arah masalahmasalah yang semula dianggap bukan isu politik seperti kesejahteraan anak, perlindungan terhadap reproduksi perempuan dan sebagainya yang tentu didorong komunikasi politik di dalamnya. Politisi perempuan yang memiliki keahlian komunikasi politik yang mumpuni memiliki kesempatan untuk dapat terpilih dalam lingkaran politik (Susilo \& Nisa, 2018).

Penelitian yang dilakukan oleh Suryani (2010) mengenai partisipasi dan peran perempuan dalam komunikasi politik, hasilnya menunjukkan bahwa adanya faktor yang mempengaruhi partisipasi dan peran perempuan yaitu dukungan partai politik, dukungan keluarga, memperjuangkan hak-hak perempuan dan membangun citra positif partai politik. Hasil tersebut tidak jauh berbeda dari penelitian Hidayah dan Munandar (2013) yang menemukan bahwa faktor yang memengaruhi perempuan dalam berpartisipasi politik ada dua, yaitu faktor internal dan eksternal. Faktor internal meliputi adanya pengaruh orang tua yang bergelut di dunia politik sehingga mampu memberikan pengrauh ke anak atau saudara. Faktor eksternal adalah adanya klaim dari desa setempat bahwa desa tersebut menjadi pendukung salah satu partai politik tertentu. Faktor terakhir adalah ekonomi yang mendorong perempuan kebanyakan memberikan partisipasinya atas dasar banyaknya pemberian dari Caleg. Selain faktor yang mempengaruhi, ditemukan adanya faktor yang menjadi kendala seperti, kondisi geografis, money politic, gender dan kurangnya percaya diri. Hasil penelitian Ainiyah (2017) menunjukkan faktor yang menjadi kendala strategi komunikasi politik perempuan dalam komunikasi politik adalah beban ganda yang disandang perempuan, minimnya SDM karena tingkat pendidikan, dan ekonomi. Beberapa penelitian lain (Zukhruf, 2012; Kollo, 2017; Sarinastiti \& Fatimah, 2019) juga membahas faktor yang mempengaruhi partisipasi perempuan dalam politik.

Sejalan dengan Nimmo (2011) yang menyampaikan mengenai beberapa faktor yang mempengaruhi partisipasi politik: (1) peluang resmi, artinya adanya kesempatan sesorang terlibat dalam partisipasi politik karena dukungan dan kebijakan-kebijakan negara. (2) sumber daya sosial, artinya partisipasi ditentukan oleh kelas sosial dan perbedaan geografis. (3) Motivasi personal, motif yang diarahkan dari dalam diri sendiri atau dari luar.

Salah satu cara yang tepat untuk mendapatkan dukungan perempuan diungkapkan oleh Zamroni (2016) dalam penelitiannya, yaitu dengan mengikutsertakan perempuan ke dalam stuktur kepengurusan organisasi partai politik, karena perempuan merupakan bagian besar dari suatu populasi yang dukungan bagi partai sangatlah penting. Hal ini juga dinyatakan oleh Wahid (2013) bahwa partai politik sangat penting dalam peningkatan kualitas politik perempuan. Demikian halnya ketika rekrutmen calon pemimpin daerah yang didukung maju pada pemilukada seharusnya partai politik lebih dulu mengutamakan kader partai yang potensial, militant, loyalitas tinggi dan memiliki kemampuan dalam pemerintahan sehingga mampu mengkomunikasikan dengan baik partainya. Hal tersebut juga didukung dengan pernyataan Sumiarni (2004) bahwa perlu adanya orientasi politik yang juga mengutamakan hakhakperempuan dalam panggung politik. Beberapa penelitian tentang partisipasi perempuan dalam politik juga telah dilakukan Hardjaloka (2012), Rodiyah (2013), Ardiansa (2016), Yulyana (2017), Lotulung dan Mulyana (2018).

\section{Teori Standpoint}

Teori standpoint milik Sandra Harding dan Julian T. Wood memaparkan bahwa laki-laki dan perempuan mepunyai perspektif yang terpisah, 
dan tidak dipandang sebagai sesuatu yang setara. Masyarakat menganggap bahwa perempuan sebagai kelompok minoritas yang mempersepsi dunia secara berbeda dengan kelompok mayoritas yaitu laki-laki. Dasar filosofi dari teori ini adalah anjuran adanya perjuangan terhadap diskriminasi gender. Gender yang dimaksud oleh Sandra Harding dan Julian T. Wood yaitu tidak mencirikan perbedaan gender pada biologis, insting maupun intuisi, namun perbedaan sebagai harapan budaya akan perlakuan kelompok untuk menerima kelompok lain (Griffin, 2006). Budaya disini dipahami sebagai aturan hirarkhi sehingga kelompok yang mempunyai posisi cenderung menawarkan kekuasaan, dan kesempatan pada anggotanya. Teori stand point menyatakan bahwa perempuan terposisikan pada sebuah hirarkhi yang lebih rendah dibandingkan laki-laki, sehingga dalam sebuah sistem makna, gender dimaknai bahwa posisi laki-laki dan perempuan kebanyakan dipisahkan secara lingkungan, material, dan simbolis.

Budaya patriarki yang disampaikan teori gender melihat perbedaan perempuan dan lakilaki secara biologis yang menimbulkan perbedaan peran gender dalam kehidupan yang lebih luas, yaitu kehidupan sosial. Teori ini membawa harapan baru yang dapat mempengaruhi cara pandang seseorang dalam melihat relasi antara laki-laki dan perempuan, yaitu persamaan hak dan kedudukan dalam setiap lini kehidupan. Hal ini juga sejalan dengan penelitian yang dilakukan oleh Mukarom (2008) bahwa, upaya counter komunikasi politik yang pertama perlu dilakukan oleh perempuan adalah dengan pengarusutamaan gender (gender mainstream). Hal ini didasarkan pada Inpres No. 9 tahun 2000, yang mendorong perhatian masalah gender untuk semakin ditingkatkan. Dengan pemahaman perspektif gender dan sensitif gender di kalangan pengambil kebijakan seperti badan eksekutif dan lembaga legislatif juga terus dikembangkan, sehingga berbagai kebijakan dan instrument hukum yang berbasis kepentingan perempuan mulai terwujud. Beberapa penelitian (Suciptaningsih, 2010; Sahi, 2012; Nimrah dan Sakaria, 2015) terkait budaya patriarki terhadap peran perempuan di dunia politik juga sudah dilakukan.

Melihat pentingnya gender mainstream dalam komunikasi politik perempuan, sehingga keterlibatan perempuan sebagai bagian yang potensial untuk turut masuk dalam dunia politik melalui peran menjadi hal pokok yang dibahas. Tujuan penelitian ini untuk menganalisis peran perempuan dalam komunikasi politik pada pemilihan umum di Daerah Istimewa Yogyakarta.

\section{Metode Penelitian}

Jenis penelitian ini tergolong dalam bentuk studi kasus tunggal. Sebagaimana dikatakan (Sutopo, 2002) suatu penelitian dikategorikan studi kasus tunggal, bilamana penelitian tersebut terarah pada satu karakteristik. Penelitian tersebut hanya dilakukan pada satu sasaran (satu lokasi, atau satu subjek). Jadi yang terpenting bukan jumlah lokasi atau sasaran studinya, tetapi adanya perbedaan karakteristik atau kesamaannya. Subjek dalam penelitian ini adalah politisi perempuan di DPRD DIY. Objek peneliti adalah peran perempuan dalam komunikasi politik pada pemilihan umum di DIY, sehingga pendekatan yang digunakan yaitu fenomenologi dimana makna dipahami dari berbagai peristiwa dan interaksi manusia yang terjadi pada situasi khusus (Sutopo, 2002). Fenomenologi menjadikan pengalaman hidup yang sesungguhnya sebagai data dasar dari realita (Kuswarno, 2006). Selain itu, data diperoleh dengan melakukan in-depth interviewning (wawancara mendalam) pada perwakilan perempuan yang ada pada 4 fraksi di DPRD-DIY, observasi dilakukan dengan melihat aktivitas politisi perempuan, terutama pada komunikasi politik yang dilakukan. Mengkaji dan menganalisis data melalui dokumentasi yang telah dikumpulkan yang berkaitan dengan masalah penelitian. Penelitian ini menggunakan teknik analisis data model interaktif milik Miles dan Michael (2006). 


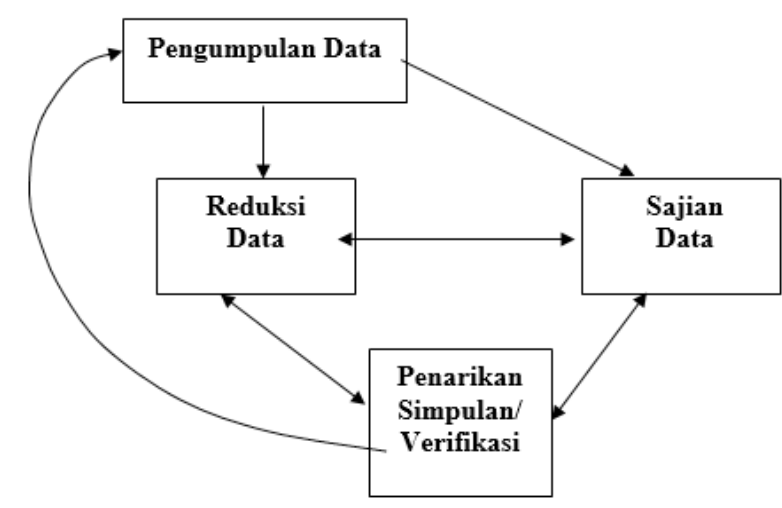

Gambar 1. Teknik Analisa Data Model Interaktif Sumber: Miles dan Michael (2006)

Pengumpulan data dilakukan melalui wawancara terhadap informan dan juga observasi lapangan. Selanjutnya yaitu, keabsahan data dilakukan dengan memanfaatkan sesuatu yang ada diluar data yang kemudian dilakukan pembandingan dan pengecekan terhadap hasil penelitian. Keabsahan data dilakukan dengan teknik trianggulasi yaitu pertama, melakukan perbandingan data wawancara dan observasi. Kedua, melakukan konfirmasi dengan subjek penelitian yaitu perwakilan perempuan di empat fraksi DPRD-DIY dan membandingkan satu dengan yang lainnya untuk mendapatkan data yang tepat. Ketiga, membandingkan hasil wawancara dan dokumen yang berkaitan, seperti; buku, transkrip, audio visual serta kegiatan komunikasi politik dan juga peran perempuan dalam pemilihan umum DIY.

\section{Hasil Penelitian dan Pembahasan}

Representasi perempuan merupakan bagian utama apabila berbicara mengenai kesetaraan gender demokrasi. Dapat dikatakan bahwa demokrasi akan lengkap ketika perempuan terlibat di dalamnya. Persentase perempuan yang menjadi Caleg pada Pemilu 2019 sedikit mengalami peningkatan dibandingkan dengan Pemilu 2014. Dari sisi jumlah dan persentase Caleg DPR, misalnya, dari total 6.607 Caleg pada Pemilu 2014, sebanyak 2.467 di antaranya perempuan atau $37,67 \%$. Adapun pada Pemilu
2019, persentase keterwakilan perempuan mencapai 40,08\%, yakni ada 3.200 perempuan dari 7.985 caleg yang memperebutkan 575 kursi DPR (Kompas.com, diakses pada tanggal 17 Februari 2020). Percaturan politik daerah pun hal yang sama juga terjadi, peningkatan jumlah keterwakilan perempuan menjadikan demokrasi lebih adil meskipun, keterwakilan perempuan di parlemen masih di bawah kuota yang diberikan yaitu di bawah 30\%.

\section{Partisipasi Politik (Affirmative Action) Perempuan Dalam Pemilihan Umum DIY}

Partisipasi politik yang berkaitan dengan affirmative action akan fokus pada bentuk keterlibatan perempuan dalam proses pengambilan keputusan baik secara formal pada institusi politik. Paratisipasi politik ini didasari oleh pentingnya peran perempuan di ranah politik khususnya berkaitan dengan upaya membentuk masyarakat demokrasi dengan ditandai oleh keseimbangan partisipasi dan perwakilan politik antara perempuan dan laki-laki (Fuchs dan Hoecker, 2004).

Pemikiran tersebut juga didasari oleh perbedaan kebutuhan antara perempuan dan laki-laki, sehigga keseimbangan keterwakilan perempuan diharapkan akan menelurkan kebijakan-kebijakan yang tidak hanya menguntungkan perempuan saja, akan tetapi lebih dari itu, yaitu terwujudnya prinsip kesetaraan politik (political equality) dalam sistem politik demokrasi. Dasar lain yang melatarbelakangi hal tersebut adalah agar perempuan dapat memiliki kekuatan mempengaruhi (influential voice) yang kemudian membantu mereka dalam membentuk sebuah koalisi yang dapat meningkatkan pengaruh dalam proses pengambilan keputusan.

Pada pemilihan umum DIY 2019, keterwakilan perempuan sudah sangat baik, merujuk pada data di bawah ini, keterwakilan perempuan sudah melebihi kuota 30\% 


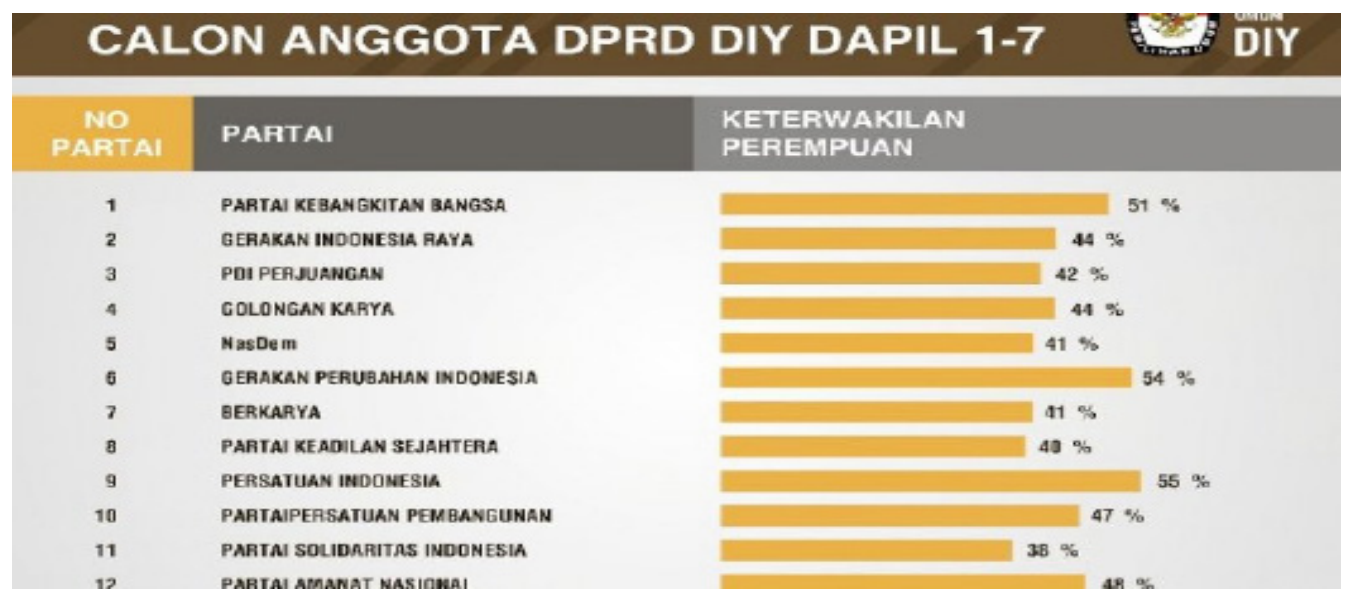

Sumber: Tribunnews.com (2019)

Gambar 2. Data pemilu 2019 KPU DIY

Persentase keterlibatan perempuan dalam kegiatan kepartaian maupun pemerintah di DIY tentu dapat dikatakan baik, mengingat dari persentase keterlibatan perempuan pada pemilu 2019 mengalami peningkatan. Sehingga yang dapat disimpulkan bahwa kuota $30 \%$ yang ditetapkan pemerintah, tidak lantas mendiskriminasikan para perempuan dalam kontestasi politik, namun mendorong adanya politik yang lebih demokratis di DIY. Seperti yang disampaikan oleh anggota komisi B DPRD-DIY:

"Kesetaraan gender harus mainstreaming atau jadi pengarusutamaan, sehingga menjadi penting untuk terus mendorong perempuan di DIY agar masuk ke ranah publik maupun politik. Perempuan tidak hanya terlibat dalam urusan domestik saja, namun juga memerlukan aktualisasi diri yang juga dapat menunjukkan daya saingnya dengan laki-laki" (Dr. Hj. Yuni Satia Rahayu, SS., M. Hum, 21 Februari 2020). Tantangan kedepan untuk politisi perempuan khususnya di DIY dirasa lebih berat dibanding laki-laki, dan dari segi pendekatan program lebih mudah dilakukan kepada masyarakat kalangan perempuan, sedangkan pendekatan dikalangan laki-laki lebih banyak membahas uang. Melihat hal tersebut partisipasi politik yang dilakukan yaitu dengan melakukan penawaran isu-isu yang dekat dengan kepentingan perempuan seperti pendidikan, kesehatan, pemberdayaan warga, serta perlindungan perempuan dan anak.

\section{Perempuan Sebagai Komunikator Politik dalam Pemilihan Umum DIY}

Komunikasi politik dalam pemilihan umum merupakan bagian yang tidak terpisahkan. Setiap partai politik menggunakan saluran-saluran informasi yang efektif dalam menyampaikan pesan politiknya. Salah satu saluran yang digunakan yaitu melalui perwakilan partai yang masuk dalam panggung politik. Dalamkonteks ini tentu berkaitan dengan perempuan dan peranya sebagai komunikator pada pemilihan umum di DIY. Komunikator politik mewakili kepentingan kelompok, dan juga menetapkan tujuan kebijakan yang lebih luas, mengusahakan reformasi, dan bahkan mendukung revolusioner (Nimmo, 2011).

Komunikator dalam komunikasi politik dapat berwujud individu, lembaga, maupun kumpulan orang. Seorang tokoh masyarakat atau pejabat, bahkan rakyat juga dapat bertindak sebagai sumber dalam komunikasi politik dan dapat dikatakan sebagai sumber individu. Pada kesempatan yang lain, memang secara jelas dapat dibedakan bahwa meskipun seseorang individu yang berbicara, tetapi menjuru bicarai suatu lembaga atau organisasi, maka pada saat itu dapat dipandang sebagai collective source atau sumber kolektif (Zamroni, 8:2016).

Perempuan yang aktif dalam panggung politik atau lembaga legislatif, maupun organisasi masyarakat memiliki 
kemampuan sebagai komunikator politik baik sebagai sumber individu maupun kolektif. Pada peran ini, perempuan lebih mengusahakan komunikasi politik dalam bentuk partisipasi langsung. Sebagaimana yang diungkapkan oleh anggota komisi A:

"Pendekatanlowpowerdistanceataulangsung lebih cenderung dilakukan, seperti masuk pada organisasi perempuan, RT, RW, PKK, bisa sampai $100 \%$ pendekatan langsung”, (Dra. Hj. Siti Nurjannah, 21 Februari 2020).

Hal ini terlihat bahwa perempuan dapat menjadi media penghubung ke masyarakat dan juga menjembatani kepentingan perempuan secara khusus, dan masyarakat secara umum. Peran perempuan sebagai komunikator politik juga dapat dilihat dari beberapa fraksi di DPRD-DIY yang melibatkan perempuan pada bidang pemerintahan, bidang perekonomian, bidang kesejahteraan masyarakat, hingga pada badan pembentukan peraturan daerah.

Faktor yang Memengaruhi Peran Perempuan dalam Pemilihan Umum DIY

Beberapa faktor yang memengaruhi peran perempuan dalam pemilihan umum DIY, yaitu:

\section{Tingkat Pendidikan Perempuan dan Kemandirian ekonomi (Tingkat Penghasilan dan Jenis Profesi)}

Tingkat pendidikan sangat mendorong terciptanya partisipasi politik di tengah warga masyarakat. Semakin baik tarafpendidikan, maka akan di imbangi dengan naiknya aksesabilitas terhadap sumber-sumber informasi, dan dijadikan bahan pertimbangan masyarakat untuk turut berkiprah di panggung politik (Almond, 1974).

Perempuan yang memiliki kemandirian ekonomi cenderung menganggap bahwa berpolitik bagian dari hak. Begitu juga pada perempuan dalam komunikasi politik pemilihan umum DIY, kemandirian ekonomi pada calon anggota legislatif dimaknai sebagai kemampuan mereka secara mandiri untuk dapat memimpin dan memperjuangankan aspirasi masyarakat.
Hal ini di dukung oleh pernyataan Weyner (Almond, 1974), partisipasi politik akan semakin luas salah satunya ditandai dengan munculnya kelas pekerja dan memberi penekanan pada peluang siapakah yang dapat berpartisipasi dalam pembuatan keputusan politik dan memberi perubahan pola partisipasi politik. Pada kajian feminis dijelaskan bahwa tujuan dari feminism adalah untuk mendorong perubahan ke arah kesetaraan antara perempuan dan lakilaki (Macionis, 2012) sehingga kemandirian secara ekonomipun merupakan hak perempuan.

\section{Nilai Budaya}

Nilai budaya yang dianut dan menjadi dasar tindakan setiap individu. Masyarakat jawa konvensional lebih menganggap perempuan lebih cocok ketika berada pada sektor domestik (keluarga atau rumah) yang kemudian terbawa pada sektor publik, yang mengutamakan laki-laki dibanding perempuan sehingga memunculkan budaya patriarki. Hal ini yang kemudian memberikan pandangan dan tantangan bagi perempuan dalam ranah politik yang didominasi oleh laki-laki. Sudut pandang agama juga mempengaruhi pandangan masyarakat terhadap kepemimpinan perempuan, yang dalam ajaran agama tertentu ditafsirakan, bahwa kepemimpinan terletak pada laki-laki. Pengaruh dari sisi keluarga lebih cenderung pada budaya patriarki yang mana kepala keluarga cenderung menjadi penentu suara keluarganya diberikan, sehingga posisi ini membuat perempuan tidak berdaya untuk memilih caleng perempuan.

Faktor di atas menunjukkan bahwa masih adanya ketimpangan peran dan relasi gender yang perlu ditinjau kembali. Perempuan dalam kacamata feminis masih melihat bahwa kodrat perempuantidakditentukansecarabiologisnamun oleh budaya di dalam masyarakat (Bryson, 1992). 


\section{Sistem Politik}

Merujuk pada sistem politik yang sudah jelas diatur dalam UU No. 12 Tahun 2003 mengenai legitimasi keterwakilan perempuan sebagai caleg partai politik dengan kuota $30 \%$. Diperkuat lagi dengan pasal 53 mengenai bakal calon peserta pemilu harus memuat paling sedikit $30 \%$ keterwakilan perempuan. Hal tersebut bertolak belakang dengan aturan ambang batas parlemen (parliamentary threshold) dimana setiap partai politik harus memperolehan suara minimal partai politik dalam pemilihan umum untuk diikutkan dalam penentuan perolehan kursi di Dewan Perwakilan Rakyat dan Dewan Perwakilan Rakyat Daerah. Hal inilah yang kemudian berpengaruh terhadap semangat perempuan yang ingin ikut berkiprah dalam panggung politik daerah khususnya di DIY.

Pembahasan mengenai partisipasi dan keterwakilan perempuan dapat memberikan peluang besar bagi demokrasi Indonesia dan penegakan hak asasi manusia. Terkait hal tersebut hak asasi perempuan dalam politik juga merupakan hal yang penting, salah satunya adalah hak untuk turut berpartisipasi dalam pemerintahan. Begitu juga yang terjadi dalam pemilu DIY, keterwakilan perempuan menjadi penting dengan memberi peluang bagi perempuan memperjuangkan kepentingan perempuan. Peran perempuan dalam panggung politik daerah sangat penting mengingat kenyataan bahwa mayoritas pemilih di Indonesia adalah perempuan. Pada pemilu DIY, perempuan telah mampu menciptakan kesadaran tentang pentingnya mengakomodasi perempuan di parlemen, terutama untuk perempuan menduduki jabatan setrategis. Upaya ini juga merupakan bagian untuk menciptakan keadilan bagi seluruh rakyat Indonesia.

Partisipasi politik perempuan (partisipasi affirmative action) dalam pemilihan umum merupakan realisasi dari bentuk politik gender, sehingga tidak hanya dianggap sebagai alat untuk meningkatkan partisipasi politik perempuan di ranah publik. Hal ini merujuk pada hasil penelitian yang dilakukan Izdiha (2017), bahwa politik merupakan jalan terbaik untuk memperhatikan kebutuhan perempuan, dan penghapusan diskriminasi. Lahirnya UU No. 12 Tahun 2003 tentang keterwakilan perempuan di tingkat DPR, DPRD Provinsi, dan DPRD Kabupaten atau kota sekurang-kurangnya 30 persen menjadi sebuah gerakan yang berimplikasi pada kesetaraan gender, dimana perempuan dapat langsung terlibat dalam perumusan kebijakan dan mampu mempengaruhi proses pengambilan keputusan yang berisi kepentingan perempuan.

Tingginya persentase partisipasi perempuan dalam pemilu DIY 2019 juga menunjukkan adanya kesetaraan gender sebagaimana telah diungkapkan di atas dalam stand point theory milik Sandra Harding dan Julian T. Wood, yang memberi cara pandang baru terhadap kesetaraan hak laki-laki dan perempuan. Sehingga dalam analisis ini, caleng perempuan sudah mulai dipercaya memimpin oleh masyarakat. Kecenderungan menempatkan perempuan dalam sektor domestik (keluarga atau rumah) juga sudah mulai berkurang. Perempuan sudah mulai menunjukkan sisi kemandirian ekonomi dengan memiliki profesi. Perempuan dapat menentukan arah politik tanpa harus terdoktrin dengan keputusan kepala keluarga.

Cara yang ampuh bagi partai politik untuk memperoleh dukungan perempuan yaitu dengan menempatkan perempuan dalam organisasi partai politik. Perempuan tidak hanya lagi menjadi vote getter dalam pemilihan umum, namun dilihat dari kapasitas dan kapabilitas diri. Keterlibatan perempuan di DIY masih ada yang menggunakan sebagai vote getter, namun dalam kepemimpinan, perempuan berani menunjukkan bahwa kapasitas dan kapabilitas dalam ranah politik tidak diragukan lagi. Hal ini juga disampaikan oleh Zamroni (2016) bahwa peran perempuan yang secara spesifik dijelaskan sebagai selebritis dan masuk menjadi kader partai politik tentu memiliki peran strategis meskipun beberapa 
partai masih menggunakanya sebagai pendulang suara (vote gatter) semata. Masyarakat DIY juga sudah mulai cerdas dalam menentukan pilihan, tidak hanya melihat dari tampilan fisik, caleg perempuan memiliki kapasitas yang mumpuni, mereka mampu untuk meyakinkan pemilih dan ketika menduduki jabatan politik akan mampu menjadi mitra setara bagi laki-laki dalam pengambilan kebijakan yang responsif gender.

Perempuan sebagai komunikator politik dalam pemilihan umum DIY. Tidak berbeda dengan laki-laki, perempuan juga mampu berperan aktif menjadi seorang komunikator politik. Talcot Parsons menyatakan bahwa pembagian peran antara laki-laki dan perempuan tidak didasarkan pada disrupsi dan kompetisi namun lebih kepada melestarikan harmoni dan stabilitas di dalam masyarakat (Parsons dan Bales, 1955). Pada pemilihan umum DIY, posisi perempuan ketika menjadi komunikator politik ditunjukkan dengan peranya untuk menyuarakan kebijakan-kebijakan yang berpihak pada perempuan. Selain itu, yang dapat dijumpai bahwa perempuan yang masuk dalam pemilihan umum DIY adalah perempuan yang sebagian besar memang aktif dalam organisasi perempuan, organisasi sosial masyarakat, dan bahkan pernah mejabat sebagai pejabat publik. Hasil ini selaras dengan penelitian yang dilakukan oleh Mukarom (2008) bahwa upaya counter komunikasi politik yang pertama perlu dilakukan oleh perempuan adalah dengan pengarusutamaan gender (gender mainstream).

Keberanian perempuan untuk masuk dalam panggung politik memberikan ruang diskusi yang baik, sehingga perlu upaya untuk mencapai kekuatan perempuan dalam politik itu sendiri. Tanpa kemampuan komunikasi politik yang baik, maka cenderung perempuan akan menjadi 'muted group', yang keberadaannya tidak terlalu berarti bagi proses politik itu sendiri (Wahid, 2012). Tentu kondisi ini bukan bagian dari implikasi substansi perjuangan 'affirmative action, kuota 30 persen keterwakilan perempuan di Pemilihan umum DIY.

Pada pemilihan umum DIY, empowering role yang dapat dilihat yaitu, sebagian besar dari anggota legislatif berpendidikan tinggi. Hal ini berkaitan dengan semakin dipertimbangkanya tingkat pendidikan untuk semakin mendukung kepemimpinan perempuan. Merujuk pada salah satu prinsip dasar dalam feminisme yaitu penghapusan stratifikasi gender dengan adanya penolakan norma budaya yang membatasi kesempatan perempuan dan laki-laki untuk memperoleh pendidikan dan pekerjaan dan upah yang layak (Macionis, 2012). Hal berikutnya yaitu kemandirian ekonomi yang dapat memunculkan kepercayaan diri perempuan yang dapat dicirikan dengan bekerja dan memiliki penghasilan pribadi. Hal ini terlihat pada para legislatif di DPRD DIY yang memang secara finansial memiliki kemandirian ekonomi yang dicirkan dengan kemampuan untuk maju dalam panggung politik pemilihan umum, memiliki pekerjaan dan penghasilan pribadi.

Peran perempuan dalam aktifitas politik dan organisasi masyarakat menjadikan terkikisnya budaya patriarki dan penafsiran sempit terhadap ajaran agama. Perempuan yang terlibat dalam pemilihan umum DIY, sebagaimana diungkapkan oleh anggota komisi di DPRD DIY memiliki keterkaitan erat dengan organisasi masyarakat dan peran perempuan di dalamnya. Selain pernah menjabat menjadi tokoh masyarakat, perempuan yang masuk dalam pemilihan umum DIY juga aktif dalam organisasi masyarakat serta berkiprah dalam ruang publik. Perempuan sebagai elemen civil society memiliki tempat yang khusus dalam meletakkan dirinya untuk mendorong demokratisasi dan melakukan upaya penyadaran kepada rakyat bahwa mereka punya hak untuk didengar oleh negara (Choiriyati dan Wiendijarti, 2011). Hal tersebut tentu berkaitan dengan kepentingan perempuan yang tertuang dalam sebuah kebijakan. 
Penerapan sistem politik yang terbuka atau demokratis dan kebijakan affirmative action mendorong terwujudnya kuota 30 persen bagi perempuan. Penetapan kuota 30 persen tersebut dipercaya oleh perempuan yang terlibat dalam pemilihan umum DIY semakin mendorong untuk terus maju dan berkiprah di panggung politik. Hal ini tentunya didukung oleh partai politik dengan melakukan pendidikan politik dan juga memberi akses lebih luas pada perempuan dengan menempatkanya dalam posisi-posisi setrategis dalam organisasi. Gambaran dari peran perempuan dalam pemilihan umum Daerah Istimewa Yogyakarta terlihat pada gambar 3 .

Berdasarkan gambar 3 dapat diketahui bahwa, subjek pada pemilihan umum di Daerah Istimewa Yogyakarta adalah 'perempuan'. Semangat kesetaraan gender menjadikan perempuan bagian dalam panggung politik daerah. Komunikasi politik perempuan menjadi hal yang penting untuk diperhitungkan, karena dalam hal ini, perempuan dapat menjadi patner laki-laki dalam strategi komunikasi politik sebuah partai politik. Selain itu gender mainstream adalah salah satu bentuk strategi untuk mencapai kesetaraan gender yang akan menjadikan tolak ukur apakah perempuan dan laki-laki memiliki hak, kesempatan, partisipasi,

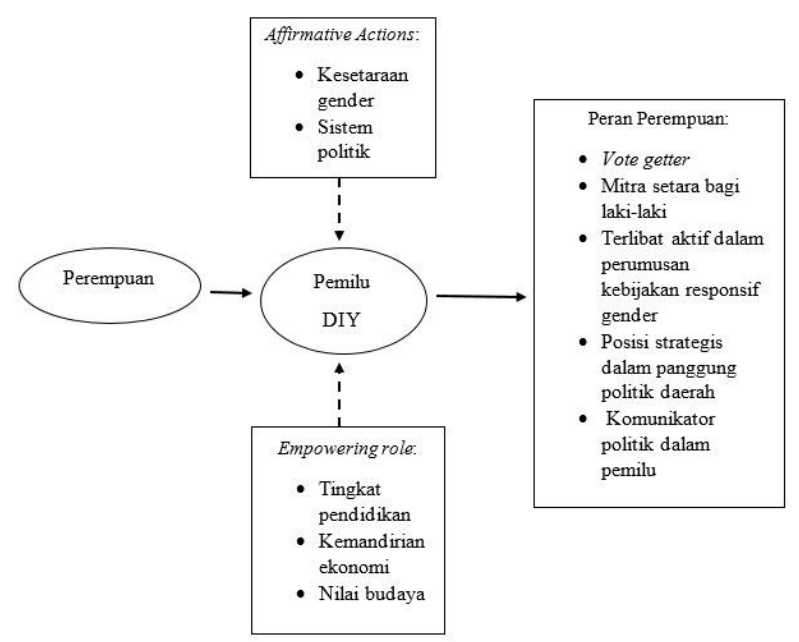

Gambar 3. Peran Perempuan dalam Pemilu DIY Sumber: Hasil olah data peneliti (2020) peran dan kontrol yang sama dalam panggung politik daerah, tingkat pendidikan perempuan, kemandirian ekonomi dan nilai budaya yang menjadikan perempuan memiliki kegiatankegitan yang mampu meningkatkan wawasan berpolitik yang lebih luas. Kemandirian yang muncul dalam diri perempuan menjadikan perempuan untuk tampil lebih percaya diri dalam panggung politik DIY yang tidak lagi dibatasi oleh nilai-nilai budaya patriarki. Peran perempuan dalam pemilihan umum DIY adalah; 1) peran perempuan dalam pemilihan umu di DIY tidak terlepas dari bagian dalam pendulang suara (vote getter) bagi para pemilih perempuan, hal ini terlihat dalam aktivitas yang dilakukan oleh anggota legislatif yang aktif dalam kegiatan ormas perempuan serta kegiatan-kegitan yang melibatkan perempuan. 2) perempuan dalam pemilihan umum di DIY dapat menjadi patner yang lues bagi laki-laki guna mencapai strategi komuikasi politik partai politik di tengah masyarakat. 3) Terlibat aktif dalam perumusan kebijakan responsif gender, dimana perempuan di DIY dapat terlibat dalam perumusan kebijakan yang berhubungan dengan relasi antara laki-laki perempuan seperti; kekerasan dalam rumah tangga, UU perkawinan, kesehatan ibu dan anak, pelecehan seksual terhadap perempuan dan anak, kekerasan terhadap tenaga kerja wanita di luar negeri. Hal tersebut tentu harus mendapatkan dukungan dari partai politik maupun kebijakan pemerintah, untuk dapat menempatkan perempuan dalam posisi strategis dalam panggung politik DIY; seperti menempatkan perempuan dalam setiap komisi di DPRD DIY. 4) Komunikasi politik perempuan dalam pemilihan umum tidak terlepas dari peran perempuan sebagai komunikator politik, yaitu menjadi media penghubung ke masyarakat dan juga menjembatani kepentingan perempuan secara khusus, dan masyarakat secara umum di DIY. 


\section{Simpulan}

Peran perempuan dalam pemilihan umum Daerah Istimewa Yogyakarta dilihat dari: 1) Partisipasi politik (Partisipasi Affirmative Action) dengan mendorong adanya politik yang lebih demokratis di DIY, adanya kesetaraan gender, tidak hanya menjadi vote getter dalam pemilihian umum, namun mampu menjadi mitra setara bagi laki-laki dalam pengambilan kebijakan yang responsif gender; Tegaknya hak asasi perempuan dalam panggung politik daerah; Menciptakan kesadaran tentang pentingnya mengakomodasi perempuan di parlemen, terutama untuk perempuan menduduki jabatan setrategis; Adanya upaya untuk menciptakan keadilan bagi seluruh rakyat Indonesia; 2) Perempuan sebagai komunikator politik dalam Pemilihan Umum DIY dapat dilihat dari beberapa fraksi di DPRD-DIY yang melibatkan perempuan pada bidang pemerintahan, bidang perekonomian, bidang kesejahteraan masyarakat, hingga pada badan pembentukan peraturan daerah; 3) Empowering role, yaitu tingkat pendidikan sangat mendorong terciptanya partisipasi politik di tengah warga masyaraka; perempuan yang memiliki kemandirian ekonomi akan cenderung menganggap bahwa berpolitik bagian dari hak; nilai budaya, peran perempuan dalam aktifitas politik dan organisasi masyarakat menjadikan terkikisnya budaya patriarki dan penafsiran sempit terhadap ajaran agama.

Penelitian ini memberikan rekomendasi kepada pemerintah serta masyarakat untuk meningkatkan pemahaman dan kesadaran perempuan melalui peran aktif pemerintah daerah dan juga politisi perempuan dengan memberikan sosialisasi, seminar maupun gerakan masyarakat serta kegiatan pendampingan; Mendorong perempuan untuk masuk dalam organisasi guna memperkuat posisi sosial di masyarakat; Mampu meningkatkan kemandirian perempuan, sehingga posisi tawar saat berkomunikasi dan memperjuangkan kepentingannya kan semakin kuat; Menguatkan dan melanjutkan kebijakan alternatif mengenai kuota $30 \%$ perempuan di panggung politik.

\section{Daftar Pustaka}

Ainiyah,N.(2017). Komuniksi PolitikPerempuan (Strategi Komunikasi Politik Perempuan Fatayat Situbondo dalam Hegemoni Politik Priyayi). JurnalLisan Al-Hal, 11(2), 307-330.

A 1 mond, G. (1974). Comparative Politics Today: A World View. Boston Torronto: Little Brown and Company Ardiansa, D. (2016). Menghadirkan Kepentingan Perempuan dalam Representasi Politik di Indonesia. Jurnal Politik, 2(1), 71-99. https://doi.org/10.7454/jp.v2i 1.82 Bryson, V. (1992). Feminist Political Theory. Basingstoke: Macmillan. Choiriyati, W., \& Wiendijarti, I. (2011). Popularitas Selebriti sebagai Komoditas Politik. Jurnal Ilmu Komunikasi, 9(2), 128142. Diakses dari http://jurnal.upnyk.ac.id/ index.php/komunikasi/article/view/3423 Fuchs, G., \& Hoecker, B. (2004). Without Women Merely a Half-Democracy. Germany: Friedrich-Ebert-Stiftung. Griffin,E..(2006).AFirstLookAtCommunication

Theory. Boston: Mc GrawHill. Hardjaloka, Loura. (2012). Potret Keterwakilan Perempuan dalam Wajah Politik Indonesia Perspektif Regulasi dan Implementasi. Jurnal Konstitusi, 9(2), 403-430. https://doi.org/10.31078/jk\%25x Hidayah, N., \& Munandar, M. A. (2016). FaktorFaktor yang Mempengaruhi Perempuan Desa Tasik Agung dalam Berpartisipasi Politik. Unnes Civic Education Journal, 2(1), 1-11. Diakses dari https://journal.unnes. ac.id/sju/index.php/ucej/article/view/1020 Izdiha, A. (2017). Wajah Politik Perempuan: Studi Etnografi Representasi Suara Perempuan dalam Pemilu Legislatif 2014 di Propinsi Daerah Istimewa Yogyakarta (DIY). Jurnal Pemikiran Sosiologi, 4(2), 3647. https://doi.org/10.22146/jps.v4i2.28579 Kollo, Fredik Lambertus. (2017). Budaya Patriarki dan Partisipasi Perempuan dalam Bidang Politik. Prosiding Konferensi 
Nasional Kewarganegaraan III. Universitas Ahmad Dahlan Yogyakarta. Kuswarno, E. (2006). Tradisi Fenomenologi pada Penelitian Kualitatif: Sebuah Pengalaman Akademis. Mediator, 7(1), 47-57. https://doi. org/10.24198/sosiohumaniora.v9i2.5384 Lotulung, L. J. H. \& Mulyana, D. (2018). Perempuan dalam Politik di Sulawesi Utara. Sosiohumaniora, 20(2), 138-144. https://doi. org/ 10.24198/sosiohumaniora.v20i2.14889 Macionis, J. (2012). Sociology. London: Pearson. Miles, M. B., \& Michael, H. A. (2006). Analisis Data Kualitatif. Jakarta: Rajawali Press. Muchtar, K. (2016). Komunikasi Politik dan Pembentukan Citra Partai. Jurnal Ilmu Komunikasi, 14(2), 136-147. Diakses dari http://jurnal.upnyk.ac.id/index. php/komunikasi/article/view/2127 Mukarom, Z. (2008). Perempuan dan Politik: Studi Komunikasi Politik tentang Keterwakilan Perempuan di Legislatif. Mediator, 9(2), 257-270. https://doi. org/10.29313/mediator.v9i2.1125

Nimmo, D. (2011). Komunikasi Politik, Komunikator, Pesan dan Media. Bandung: PT Remaja Rosdakarya. Nimrah, S \& Sakaria. (2015). Perempuan dan Budaya Patriarki dalam Politik: Studi Kasus Kegagalan Caleg Perempuan dalam Pemilu Legislatif 2014. The Politics, 1(2), 173-182. Diakses dari http://journal.unhas. ac.id/index.php/politics/article/view/229

Parsons, T., \& Bales, R. F. (1955). Family, Sozialization and Interaction Process. Glenco, Illinois: The Free Press. Priandi, R. \& Roisah, K. (2019). Upaya Meningkatkan Partisipasi Politik Perempuan dalam Pemilihan Umum di Indonesia. Jurnal Pembangunan Hukum Indonesia, 1(1), 106-116. https:// doi.org/10.14710/jphi.v1i1.106-116 Ratnawati. (2004). Potret Kuota Perempuan di Parlemen. Jurnal Ilmu Sosial Dan Ilmu Politik, 7(3), 295-314. https://doi.org/10.22146/jsp.11062
Rodiyah, I. (2013). Keterwakilan Perempuan dalam Dewan Perwakilan Rakyat Daerah. Jurnal Kebijakan \& Manajemen Publik, 1(1), 5569. https://doi.org/10.21070/jkmp.vli1.427 Sahi, N. A. (2012). Studi Partisipasi Politik Perempuan Gorontalo. Jurnal Ilmu Administrasi (JIA), 8(1), 1-8. Sarinastiti, N., \& Fatimah, P. S. (2019). Edukasi Komunikasi Politik dalam Menciptakan Kesadaran dan Minat Pemilih Perempuan. Jurnal Kajian Komunikasi, 7(1), 44-58. https://doi.org/10.24198/jkk.v7i1.19125 Suciptaningsih,O.A.(2010).PartisipasiPerempuan dalam Lembaga Legislatif di Kabupaten Kendal. Komunitas, 2(2), 66-73. https:// doi.org/10.15294/komunitas.v2i2.2276

Sumiarni, E. (2004). Gender dan Feminisme. Yogyakarta. Yogyakarta: Wonderful Publishing Company. Suryani, I. (2010). Partisipasi Perempuan dalam Komunikasi Politik (Studi tentang Partisipasi Perempuan dalam Komunikasi Politik di Pos Wanita Keadilan (Pos-WK) Dewan Pengurus Daerah (DPD) Partai Keadilan Sejahtera (PKS) Sukoharjo Tahun 2009). Surakarta: Universitas Sebelas Maret.

Susanto, Eko Harry. (2013). Dinamika Komunikasi Politik dalam Pemilihan Umum. Jurnal Kajian Komunikasi, 1(2), 163-172. https://doi.org/10.24198/jkk.v1i2.6041

Susilo, M. E., \& Nisa, N. L. (2018). Strategi Komunikasi Politisi Perempuan. Jurnal Ilmu Komunikasi, 16(1), 54-65. Diakses dari h t t p : / / j urna l.upnyk.ac.id/index. $\mathrm{php/komunikasi/article/view/2682}$ Sutopo, H. B. (2002). Metodologi Penelitian Kualitatif. Surakarta: UNS Press. Wahid, U. (2012). Aliansi Jaringan dalam Proses Komunikasi Politik Anggota Dewan Perwakilan Rakyat Daerah Perempuan. Jurnal Ilmu Komunikasi, 10(1), 69-84. Diakses dari http://jurnal.upnyk.ac.id/ index.php/komunikasi/article/view/87 
Wahid, U. (2013). Perempuan dan Kekuasaan Politik dalam Pemilukada DKI Jakarta Tahun 2012. Malaysian Journal of Communication, 29(1), 73-97. Diakses dari http:// ejournal.ukm.my/mjc/article/view/15037 Yulyana, E. (2017). Keterlibatan Politik Perempuan dalam Proses Legislasi DPRD Kabupaten Karawang Periode 2009-2014. Jurnal Politikom Indonesiana, 2(2), 105113. https://doi.org/10.35706/jpi.v2i2.969 Yuniati, Y. \& Fardiah, D. (2017). Citra Caleg Perempuan dalam Framing Media
Online. MediaTor, 10(1). 75-86. https:// doi.org/10.29313/mediator.v10i1.2690 Zamroni, M. (2016). Perempuan Dalam Politik (Studi Kasus Partisipasi Selebritis Perempuan Dalam Komunikasi Politik Di Partai-Partai Islam Pada Pemilu 2014 Di Indonesia). Jurnal Komunikasi Profetik, 9(1), 1-20. https://doi.org/10.14421/pjk.v9i1.1194 Zukhruf, Alfan. (2012). Partisipasi Perempuan dalam Partai Politik Berbasis Islam (Studi Kasus DPC PPP Kota Tangerang. Skripsi. Tangerang: UIN Syarif Hidayatullah. 